\title{
Small-scale Gold Mining and Trans-frontier Commerce on the Lawa River
}

\author{
Marjo de Theije
}

\section{1 Introduction}

The fluvial border that separates Suriname from French Guiana abounds with multiple meanings and functions. This frontier lies between two very different countries: Suriname is a young nation with a turbulent colonial history, now home to over twenty different ethnic and language groups; French Guiana is a small piece of Europe in South America, though involving partially different languages and populations groups. The two countries represent very different political systems and highly unequal economic realities. As a consequence, crossing the border is like stepping from one world in the other. The visitor is faced with differences in official languages and currencies, and immediately senses the differing forms and stages of development and organisation of the respective nation states. These differences have become increasingly visible over the past decades, as both countries developed in distinct directions. However, the frontier is not only shaped by states. The inhabitants of the region, the people who use the river, who make a living, by and on the river, give meaning to the frontier and re-create what nations draw on maps. Despite all the differences between Suriname and French Guiana, the inhabitants of the border region are culturally very similar, sharing languages and family ties, and also participate in the same activities. Moreover, people use the frontier itself in creative ways, despite its main role as a barrier.

It used to be the case that the frontier barely existed for many inhabitants of the region, even as an imaginary construct, since their homes and customary lands were on both sides of the river. In addition, people have always had many cross-border relationships too. Nowadays, there are, in principle, more bureaucratic limits to free movement across the frontier. At the same time, however, we witness a lack of border surveillance, long stretches of the border remain unattended by the authorities on either side, and both Maroons and Amerindians, as well as newcomers to the region, move freely between the two

(C) MARJO DE THEIJE, 2015 | DOI 10.1163/9789004280120_004

This is an open access chapter distributed under the terms of the Creative Commons Attribution-

Noncommercial 3.0 Unported (CC-BY-NC 3.0) License. 
countries. ${ }^{1}$ Crossing the border, moving to the other shore, or moving upriver or downriver, is part of everyday life for most inhabitants of the region, the Pamaka, Ndyuka, Aluku/Boni, Kari'na, and Wayana. Surinamese children from several villages that themselves do not have schools study on the French side and go there every day on the 'school boat'. Newcomers, mainly Brazilians, also move around and across the border with great ease. They, too, all have crossborder relations, and for them Suriname, French Guiana, and Brazil are all part of one and the same familiar Amazonian rainforest (Theije and Heemskerk 2009: 8-9). It is, as Ribeiro (2009: 314) defined, a single trans-frontier social space.

The meaning of this porous border is as varied as the actors. The Brazilian anthropologist who cannot cross legally from Suriname to French Guiana without a visa feels severely limited. The Maroon woman who paddles to her sister on the other bank of the river could not care less. For many people passing and living along the rivers of the French Guiana-Suriname frontier, the border is not an obstacle but rather an invisible line between national states that offers economic opportunities. For others the Lawa and Marowijne rivers (Maroni for French speakers) are just two of the many rivers in the Guyana Shield that one traverses to go into the forest, to the villages of the tribal peoples, or to the gold fields. For others it is their main economic resource: they mine gold from the riverbed, they transport goods and people across the river, or they catch fish from it, to sell or as food for their family (see also Piantoni 2011: 49-50).

In this chapter I describe how people live with the frontier between two states, more precisely the Lawa between French Guiana and Suriname. Crossborder movement in this region involves many different home locations, and an incessant process of motion and forming, changing and reforming of relationships, where borders became obsolete and the 'migration' process is a continuity of movement, and will benefit from an approach rooted in transnationalism theory (Glick Schiller et al. 1992). The specific social and cultural configuration of the movement along the Marowijne and Lawa Rivers has not been researched from the Surinamese point of view The 'migrants' in this border region include the Maroon and Amerindian inhabitants, as well as French, Surinamese, Guyanese, and Brazilian gold miners, sex workers from different backgrounds, and many merchants, vendors, hawkers from all the aforementioned countries, and many Chinese. They all are attracted by the small-scale

1 The international airport, Albina, and South Drain (Nickerie) are the only border control posts, but the high costs of monitoring leave even these three posts without sufficient control services (Jubithana-Fernand 2009: 200). 
gold mining activities in the region, on the river and on both banks of the border river, and along the many creeks and smaller rivers that drain into the Marowijne and Lawa. This brings me to the second objective of this chapter.

People do not cross these rivers empty-handed. Trade and commerce account for most of the traffic and transport. After the violent confrontation between Maroons and Brazilians in Albina on Christmas Eve 2009, the Surinamese public became aware of the magnitude of the commerce up the Marowijne River and beyond. ${ }^{2}$ The huge commercial buildings in Papatam, petrol stations and numerous transport boats, once obscured from the public in Paramaribo, were now exposed to the gaze of the nation. The northern part of the Marowijne River has always been the main gateway for traders and hawkers, and probably also for smugglers. In the past decade, this commerce has become much more intense as a result of increasing gold mining activities in the region. The place of action is an economic space where the normative and repressive roles of the nation states involved are largely ignored in a process of "grassroots globalisation", or "economic globalisation from below" (Ribeiro 2009). To date, we have few studies of how the economic linkages and arrangements are shaped between the many groups and individuals in the Guianas. To come to a better understanding of the economy of this frontier, this chapter will provide ethnographic descriptions of instances of commerce and transportation across the Lawa River.

In the following sections, I focus on the complex movements 'in and out of Suriname' along the Lawa and Marowijne Rivers that form the frontier with French Guiana. These movements are, for a large part, a consequence of smallscale gold mining in the region, on both sides of the rivers. First, in Section 2, I provide an overview of the history of the recent gold mining boom. In Section 3, I focus on the 'migrants' involved in the gold mining enterprise. In Section 4, I describe the different forms of transport, trade, and hawking, as principal economic activities in the region. In Section 5 , I focus on the trans-frontier part of the trade. ${ }^{3}$ In the conclusion, in Section 6, I return to the movements 'in and out of Suriname'.

2 The Surinamese public also became aware of the lack of State control over the area, with local policemen complicit in 'illegal' border crossings and even judging in disputes between 'illegal' traders.

3 I have been studying small-scale gold mining in Suriname since 2006, and up to my last research visit, prior to writing this article, to the upriver region in January 2012 I spent a total of 12 months doing actual fieldwork, mostly in the area around Benzdorp, Lawa region. 
In the interior of Suriname small-scale gold mining is the most important economic activity. In this sector many different stakeholders are active, from local inhabitants, Maroons from other places in the country, urban Surinamese, Brazilian garimpeiros, to foreign technicians and geologists from large mining companies involved in prospection activities. Local Aluku and Wayana are now emphasising the devastating impact that the influx of migrants caused by the mining activities has had on their territory and culture. The first migrant miners arrived in the region at the end of the nineteenth century. We can only speculate about their impact at that time.

The first gold deposits along the Lawa River were discovered by two Frenchmen in 1885 and caused a gold rush that involved not only the Aluku living in this area, but above all thousands of migrant miners. ${ }^{4}$ The migrants coming to the Lawa during the first gold rush were Creoles, some from Suriname, but most of them from the Antilles, Martinique, Guadeloupe, Saint Lucia, and other islands (Petot 1986: 121). Mostly foreign companies acquired concessions and hired personnel to carry out their operations. It must have been a real invasion, in a region that before was only inhabited by a few hundred Aluku Maroons and Wayana Amerindians. Suddenly the ethnic diversity of the (temporary) population grew tremendously: the discovery of the gold attracted thousands of foreigners and urban Creoles. The first rush only lasted a few years, but returned around the turn of the century when gold was discovered in the Inini Creek, a tributary of the Lawa upstream from the main Aluku area, but right in the middle of Wayana territory.

The Compagnie des Mines d'Or de la Guyane Hollandaise obtained the concession rights from the French discoverer of the gold reserves and produced gold in several left hand tributaries of the Lawa River until 1928 (Polak 1908: 723). In the decades that followed several other companies worked on the placer $^{5}$ until 1963. The Sarakreek Goudvelden N.V., that operated from 1935 onwards, was the first to introduce a mechanised mining system with diesel load shovels and draglines. This company also allowed a limited number, on average 145, of small-scale miners to work on the concession (Fleming 2006).

4 At that time the frontier between Suriname (the Netherlands) and French Guiana had not yet been settled; this was done in 1891 by a committee chaired by the Russian Czar, which established that the left bank of the Lawa was to be Dutch and the left bank French (Bilby 1989, 1990, Sicking 2006: 121).

5 A placer is an alluvial mineral deposit, in this case of gold, fit for open pit mining. 
There is little mention in the historical sources of large participation of the local population in the actual mining activities, although it is plausible that some may have ventured into mining themselves (cf. De Beet and Thoden van Velzen 1977: 127; Bilby 1989, 1990; Crevaux 1883: 67-8). Bilby (1989) mentions an agreement between the Aluku and the French governor, recognising the right to intervene in the gold production in the so-called Conteste 'the disputed area', claimed by both the Dutch and the French. It is also known that the Aluku of the village of Kottika on the Lawa River introduced a tax on all gold shipped to the coast (Polak 1904). The local population was not much involved in the mining enterprise itself. Ndyuka and Aluku alike only used gold as a supplement to their family incomes, and only now and then would some members of the family go to a creek known for its gold and pan gold for a week or so. This gold would be used to do the Christmas purchases or to cover some unexpected expenses. None of the contemporary Ndyuka miners I interviewed in the Benzdorp region was raised in a mining camp. Only one Aluku miner mentioned he had lived close to a placer as a child, at Benzdorp in the 196os, as his mother (who was living with a Kabiten 'Captain' of the French village Papaïchton - then Pompidou) had her kampu 'camp' there. The island Kawina Tabiki (now usually called Lawa Tabiki), right in front of the Benzdorp placer, was inhabited by Aluku and Ndyuka, but these did not generally work for the Sara Goudvelden N.V., the company that exploited the gold fields in the area between 1935 and 1963, nor for the Lawa Goldfields Ltd. that started a dredging operation in 1963. Instead, Creoles from Saint Lucia and Martinique and other Caribbean Islands formed the main workforce on the placer (Geijskes 1957 [1942]; Strobel 1998). In the 1950s and 196os, Benzdorp had a police post, about 100 houses, built by the Sarakreek Companie for their workers, shops and bars (Helman 1980). The Aluku did not live there, however, as they did not want to be employed by others. In the 196os Hurault learned that Aluku found gold mining a humiliating occupation (Hurault 1965: 91).

By the end of the 1970s, gold mining in Suriname received a new impetus, as the national Geological and Mining Service (GMD) introduced a technological innovation: small dredges on the rivers and creeks that suck gravel from the riverbeds in search of gold (Heemskerk 2000: 18). The active role of the GMD in the development of small-scale gold mining, especially under director Henk Dahlberg (see Dahlberg 1984), came to an end as a consequence of the civil war, which paralyzed the country from 1986 to 1992. The war, between the military government and the Maroon Jungle Commando, however, also caused the return of the importance of small-scale gold mining in the region, as south-eastern Suriname became isolated from the coast and men lost their access to jobs. The war was partly financed by operating the dredges that the 
insurgents had confiscated from the government in the Marowijne River. For the first time gold mining became an economic activity of the local people, rather than foreign companies or public enterprises. Many young Maroons became acquainted with small-scale gold mining in this period (Hoogbergen and Kruijt 2004; Theije and Heemskerk 2009, 2010), and continued working in this sector after the war had ended.

Thus, from the 1990s onwards, Maroons also started mining themselves, during and immediately after the civil war. Several Aluku began re-mining the old placer of Benzdorp, first manually but with the help of Brazilians soon with hydraulic equipment as well. They were very successful and others followed their example. Some set up operations in French Guiana, at the Mana River, and Dorlin. Two other significant changes took place in the early nineties. First, mining Maroons contracted Brazilian garimpeiros to work with them. The Brazilians started working on the dredges, but soon also in open pit mines in the alluvial deposits along the Lawa River, and its tributary creeks. The closing of mining sites in the Brazilian Amazon had made many independent miners available to the workforce in the neighbouring countries such as Venezuela, Guyana, French Guiana, and Suriname. The Brazilians, who had many skills and knowledge about mining techniques, introduced new mining methods and equipment to Suriname. Second, in the early 1990s the government started to grant concession rights for gold mining to several (non-Maroon) entrepreneurs from the city, as well as to the state company Grassalco (now State Mineral and Mining Company Holding). Large areas of mineable land came under their control, for which they tried to interest international companies to do the prospecting. Meanwhile, they invited garimpeiros to set up their own independent operations, against payment of $10 \%$ of the proceeds to the concession owners. Traditional land rights were largely ignored in this process and the Maroons who happened to be mining in the areas that were their customary lands, in time had to submit to the rules imposed by the concession holders. These two developments, together with the new direct involvement in mining of the riverine peoples, not only Maroons but also the Wayana Amerindians, have largely determined the face of the current gold economy in southern Suriname and French Guiana.

Small-scale gold mining is one of the main sectors of the economy of Suriname. Bauxite, gold and oil make up 95\% of all exports of the country, with gold production increasing and bauxite drastically decreasing. In 2011 gold was the most important export product. The exceptionally high gold price is making a positive contribution to economic growth in Suriname. Moreover, after the government, the gold sector creates most jobs in the country (IMF 2010: 82). The gold sector has also had an indirect impact on the economy, 
for example, the large trade in excavators, bulldozers, tractors, and ATvs (All Terrain Vehicles, quads), and of course the spare parts for all this machinery that is used to build the paths, to dig the pits and transport the people and goods (Fritz et al. 2009: 83). Gold mining also accounts for $75 \%$ of all domestic flights in Suriname (ibid: 83), and probably an even larger proportion of all river transport. Both the gold mining itself and the transportation of goods, machinery and people to the gold fields requires large amounts of petroleum products. It is estimated that annually about 15 million litres of diesel and 50,00o litres of grease are used in small-scale mining (ibid: 83). Moreover, in the interior, hardly any other economic activity exists. Research shows that $90 \%$ of households in the villages along the Tapanahoni, Marowijne and Lawa and the Brokopondo area are wholly or partially financially dependent on small-scale gold mining (Heemskerk 2009: 35). In addition, the Brazilians in the Surinamese small-scale gold sector spend much of their money in Suriname. Many Brazilians have their families in the city, and others spend most of their money on entertainment-in the gold fields or in town. Thus the money from the small-scale mining sector trickles through into almost all sectors and strata of the Surinamese economy.

\section{3}

\section{Migrants at the Lawa}

The small-scale mining sector has an extraordinarily transnational character. The dynamics of the activity are largely driven by global gold prices. When the international gold price rises, mining becomes more attractive. As a consequence, areas that were previously uninteresting because of minor finds will now be mined as the price per gram significantly increases. In addition, the sector can absorb more miners. Not only is the price of gold important, the oil price also has a major impact on business, as the biggest operational cost in small-scale mining is fuel. A second transnational influence, are the policies in other countries. The prohibition of mining in several Brazilian regions in the early 1990 caused a migration of garimpeiros towards the neighbouring countries to the north, that is French Guiana, Suriname, and Guyana.

A recent migration stream entering the Surinamese gold fields comes from French Guiana. On the French side of the Lawa River, Operation Harpie, ${ }^{6}$ aimed

6 <http://www.defense.gouv.fr/operations/france/harpie/11-03-08-guyane-la-preparation-ala-mission-harpie>: 'Harpie is an interdepartmental operation which mobilises substantial resources of the Ministries of Interior, Defence and Justice. The armed forces have been strengthened by soldiers deployed from the mainland and the Caribbean.' 
at ending small-scale gold mining, has been in force since early 2008, chasing end evicting the non-licenced miners. For this reason, an increasing number of individuals have relocated their base to Suriname. Several recent settlements along the Lawa River were founded, and grew considerably as a consequence of the repressive actions of the police and French military on the other side of the river. Operation Harpie was the follow-up of the police-only Operation Anaconda (2002-2008), whose purpose was likewise to combat illegal mining in French Guiana through the identification and destruction of gold mining equipment. It proved to be insufficient to end the mining activities, due to the difficult access to the region, and the fact that the miners appeared to be better equipped to move into the forest, and to hide from the police. The proximity of the national frontier also compounded the problem because across the river the migrant miners are hounded much less. Although small-scale gold mining in Suriname is only recently entering a process of formalisation, in the past two decades it was tolerated and on several occasions was even temporarily legalised. The 2008 Operation Clean Sweep (see note 7) in Benzdorp had no long-term consequences for the mining activities in the region, nor for the free movement of the miners and others. As a consequence, the migrants lead a more tranquil existence in Suriname, where they do not need to run from the military or police, and do not need to fear for the loss of their investments in equipment as they do in French Guiana. This calm and peaceful environment is what attracts people to live temporarily or permanently on the Surinamese side of the Lawa River where they find some respite from escaping from the French police.

Migration has always been a characteristic of the region. The Wayana and Aluku only arrived in the eighteenth and nineteenth century (Boven 2006). Formal frontiers were never any real barriers that stopped people from crossing the river or from moving to other parts of the region. Ever since their discovery, the gold fields of the Lawa played host to people from elsewhere. After the nineteenth century rush passed some migrants stayed in the region to continue as individual gold diggers on the French side. It was only on the Dutch side that some larger companies continued to produce gold (Ahlbrink 1956 cited in Boven 2006: 84). A French census from 1938 registered more than 1000 Creoles in Wakapou (the largest village in the region at that time, right opposite Benzdorp), Maripasoula and Inini Creek (Vaillant and Hurault 1960). Sarakreek Gold took over the exploitation of the Benzdorp placer in 1935 and introduced the first mechanised mining system in the Lawa area, in the Rufin Creek. This company admitted independent gold miners to work on their concession, at several different creeks. On average, 145 persons worked there per year, with a peak of 225 in 1941 (Fleming 2006: 7). This meant a renewed growth 
of the surrounding activities too, and the French Creole village Wakapou, directly opposite the landing of Benzdorp, saw a significant increase in population (Vaillant and Hurault 1960). In the same years a new group of Creoles from St. Lucia arrived in the Inini Creek gold fields (Strobel 1998: 224). Dutch biologist Geijskes passed through the area in 1938 and found 270 Creoles, employees of what he erroneously calls the concession of the Compagnie de Mines d'Or de la Guyane Hollandaise, living in Benzdorp (Geijskes 1957 [1942]: 26). On his way back he mentioned finding 600 St. Lucians in the same place (ibid: 285). Little information is available on the decades that followed. When Surinamese writer Helman visited Benzdorp and Wakapou almost twenty years later, in 1955, he found the then largest gold company of the country fully operational, with a hundred or so small houses, a police post and customs office, as well as a partly mechanised gold operation. The coming and going of foreign gold prospectors continued for some decades, but by the 1970s gold extraction had come to a standstill. The next big change occurred as a result of the civil war, a.k.a. the War of the Interior (1986-1992).

As a consequence of the war, many Surinamese Maroons fled in great numbers from their villages to Paramaribo and to French villages across the Marowijne River, such as Gran Santi, Apatou and Saint-Laurent-du-Maroni, intensifying a process that had already been taking place at a slower rate in the previous decades. Many war refugees stayed in French Guiana after the war had ended, and this in turn attracted new migrants. Increasingly the economic differences between the two countries, caused a pull and push tension, bringing many Surinamese to French Guiana. In French Guiana wages are much higher, although the price of food, shelter, clothing and entertainment is higher, too. Noteworthy is also the social security system in French Guiana, which is much more generous than its Surinamese counterpart, so it became desirable to acquire documents for this part of Europe and so obtain access to these services. Another consequence of the civil war was that a generation of (refugee) children in Suriname were left without education and professional training, and are now unschooled with few opportunities on the Surinamese job market. These young men are now the main actors in the small-scale mining activity in the interior.

Around the same time, after the war, large numbers of Brazilian miners started to arrive in Suriname. There are records of garimpeiros working in Suriname since the 1980s, yet it was not until the early 1990s that the influx of mining-related people and knowledge grew to such proportions that it began to impact Surinamese society, and the regions with most of the mines, such as up the Lawa River. Today between ten and twenty thousand Brazilians are working in Suriname, virtually exclusively in the small-scale gold mining 
industry and surrounding service economy (officially, the figures from the 2004 census (ABS 2006) are repeated till today). ${ }^{7}$ Most of these first gold fields were close to the French border, and initially many garimpeiros came over land, from French Guiana. Nowadays, most Brazilian migrants arrive on the Surinam Airways flight from Belém.

\section{Commerce on the River: Maroon Transporters, Chinese Supermarkets, and Brazilian Hawkers}

To set the context for this section, the reader may imagine a vast tropical rainforest with hardly any inhabitants and a very limited infrastructure. The people in this forest are there to work in the gold mining business. This demands a steady supply of food and fuel. The miners do not grow vegetables or staple foods. In the interior only a few Maroon women profit from the mining business by selling $k w a k(a)$ (granulated cassava meal), and some Maroon and Amerindian men sell fish or meat, but apart from that there is no local production to feed the thousands of miners in the mining camps. For this reason, everything is bought in the urban centres along the coast, mainly in Albina, on the lower Marowijne River, and in Paramaribo, to be commercialised again up river. Thus, the river, and the frontier, are a hustle and bustle of commercial activity, with many people making a living in gold mining-related sectors. With the intensification of gold mining activities and the influx of thousands of migrant miners, the dimensions of all commercial activities have increased. Albina is the place where all goods and people enter the boats to go upriver to the villages and mining camps in French Guiana and Suriname. Upstream many smaller places serve as transfer stations, where goods are waiting for buyers, or goods are put into smaller boats that bring the merchandise to the camps along the smaller creeks, or into the pick-ups and quads wherever overland transport is possible.

In the past things may not have been so very different. A century and more ago, the Ndyuka and Aluku reigned in the transport business (Thoden van Velzen 2003). De Beet and Thoden van Velzen (1977: 115) calculated that in the period $1885^{-1888}$ some 5,000 to 6,000 people arrived in the gold fields of the Lawa, and in 1901 there were again 5 ,ooo workers. Although the numbers never rose to those heights again, from then on there have been continuous

7 Although various initiatives have been taken to legalise the unregistered migrants, such as Operation Clean Sweep in 2008, this has not led to a better knowledge of the numbers of Brazilians in the country. 
mining activities in the region, mostly carried out by migrants. Although they did not venture into mining themselves, the gold rush had a large impact on the economic and social situation of the Maroons, as they were the only ones who knew how to manage transport on the rivers and creeks (see also van Stipriaan (this volume)). De Beet and Thoden van Velzen show convincingly that the Maroons "experienced a most spectacular economic upsurge" after 1880 (1977: 113). In the twenty first century the Ndyuka are still the carriers of most of the cargo from the coast to the gold fields.

Food and fuel form the largest part of the trade. In Benzdorp and other settlements some basic foodstuffs were sold in small shops, owned by locals or Brazilian women. Because these shops are very expensive, and everything is paid for in pure gold, most people send to town for their food, and have it shipped, on their own costs, to the interior. For owners of mining operations, who have to feed all workers three times a day, this means that every two or three months they send for a shipment of foodstuff. In the larger mining settlements women would start restaurants. The story of the founding of Benzdorp revolves around the bar-restaurant of Dona Maria. Dona Maria started as a cook working for gold miners, but she came up with the idea to start a bar at the time of the soccer world championship of 1998. She bought a satellite dish and television set and started to sell soft drinks and snacks. Soon she also began to cook meals on Sundays and this was such a success that she left her job with the mining crew and invested in the bar-restaurant, and later also a brothel. In the beginning there were only a few other houses, but the location of the bar of Dona Maria soon expanded into what is now known as Benzdorp, the commercial and recreational centre of a large mining area. In general, beer, liquor, and cigarettes are an important part of the market since bars and brothels are the centres of social life in the mining culture.

Over the last few years, Chinese merchants, who have been quick to move into almost any place where there were no Chinese stores yet, entered the mining area and some of the villages on the Marowijne and Lawa Rivers. This development increased the volume and variety of available products, and prices dropped considerably, but it also ruined business for small shops run by local inhabitants and Brazilians. In the space of three years, between 2007 and 2010, Chinese entrepreneurs took over the entire commerce in the gold fields on the Lawa River. In Benzdorp alone, I counted fourteen Chinese supermarkets in 2012, all selling basically the same products. Only some Brazilian clothing stores and beauty salons have survived the competition with these newcomers.

Fuel is essential for the mining enterprise and forms the largest part of the production cost of gold. Fuel is bought in Paramaribo, transported by road to 
Albina and from there on boats to landing places close to the mining sites on the Lawa River. Some miners organise this transport themselves, using the Maroon boat services between Albina and the Lawa River. Otherwise local entrepreneurs organise this part of the route, often with their own boats. Until two or three years ago, the Ndyuka were the main vendors of gasoline and diesel in the Lawa gold fields, and had quite a lucrative business. "Everything I have, here and in Paramaribo, I bought with the gold of Benzdorp," said a 32-year-old fuel vendor who started a business eight years ago. "Before I had only three pairs of trousers and three shirts, and now I have everything, also my own house." Growing competition from Chinese traders in the past few years, however, has caused most Ndyuka oil salesmen to give up this part of their trade.

Whereas all the trade described until now is located at permanent places, a major part of commerce in the interior is carried out by travelling salespersons. Mostly female hawkers (seli uman and marreteiras) also bring luxury goods such as perfumes, clothes, and cigarettes to distant places that are only accessible by canoe. They buy these goods in Brazil or Suriname and sell them in Suriname and French Guiana. Some settle temporarily in larger mining camps such as Benzdorp, sell there, and make short trips into the surrounding area to visit the small camps. Others are just itinerant workers while some stay on as cook or bartender in some place and try to sell their merchandise on the side. Sometimes they also do sex work. There is great variation in the way this commerce takes place. A cook may occasionally bring a box of perfumes and soap from Brazil (the Brazilian brands Boticário and Natura are very popular) to sell to the miners in her camp and to anyone else who might pass through. Or she may go to Paramaribo every now and then to buy such products at the local Surinamese market, and return to sell them for double the price in the Benzdorp and Antino area. If she sells it further up the river, the price may triple or rise even more. In January 2012 a perfume bought in Paramaribo for 50 Us $\$,{ }^{8}$ was sold for 5 grams of gold — at the time about 200 Us $\$$ - in the gold fields of the upper Lawa River. Such goods are transported by airplane, which is relatively cheap since these goods are not that heavy.

Quite a few women travel from garimpo (mining site) to garimpo to sell the merchandise they bring from Paramaribo or Brazil. Hawking has become their main activity and source of income. Apart from personal hygiene products, clothes are the second most popular product. Experienced women have developed sophisticated business chains, flying to Belém (from Paramaribo), then by bus to São Paulo, to buy the clothing, then they ship it to Suriname, or bring

8 In Paramaribo many imported goods are traded in us\$ prices. 
it by airplane, to sell to their compatriots in Suriname or French Guiana. The main problem these hawkers encounter is that they often sell on credit and are not always paid their due. For their business, the women often depend on hearsay about "rich garimpos" where they expect to find the buyers for their products.

All transactions are carried out in gold. Sometimes Euros or us Dollars are accepted, but the method of payment is generally in grams of pure gold that is later exchanged for currency (Us Dollars or Euros). Most of the time, Brazilians sell the gold to an official gold buyer in Paramaribo, who also offers the service of keeping the gold for some time (as in a bank account) or transferring the converted amount to the bank account of their family in Brazil. The traders immediately feel rising gold prices on the world market when they sell their gold in the city. In the mining region, however, prices are set in gold, and these tend not to fluctuate. For example, a taxi ride on a quad was ten grams of gold in 2006, when a gram of gold was US $\$ 15$, and continued to be ten grams in 2009, when a gram of gold was Us $\$ 50$. Thus, the use of gold as the main currency creates a certain stability for the small traders; at the same time, however, their business is also very vulnerable. In the past few years the arrival of new actors on the scene, the Chinese supermarkets that were opened in many places, have made the position of the smaller shops and itinerant traders much more difficult. Many traders have stopped because it was no longer profitable to compete with the new supermarkets. Whereas before many gold miners would bring most of the groceries for their crew from town, they now buy them in the Chinese supermarkets in the interior.

The critical ingredient for the economic activities in the region is that all this is taking place at the frontier of Suriname and French Guiana. From a statecentred point of view most of the trade is not according to the Surinamese state's norms and regulations since entrepreneurs do not pay import or export taxes, they do not have licenses for shops, so this trade is considered illegal, and is even labelled a criminal activity. This becomes apparent when police and military are sent to 'bring order', and a so-called (Operation Clean Sweep) is deemed necessary to control the economic activities in the settlements in the Benzdorp region, as happened in 2008. On the other side of the border, in French Guiana, this commerce is also illegal simply because the traders come from Suriname without any registration and without paying taxes. Furthermore, the French government is very committed to the eradication of illegal gold mining in French Guiana, especially in the National Park (Parc amazonien de Guyane). In this manner, therefore, commerce and hawking become smuggling. This state-centred approach does not give any insight into 
the economy of the region, nor into the various actors' points of view. I prefer to see this economic space along the Lawa River as a trans-frontier region and social space where a myriad of actors make a living and find opportunities for social mobility through specific commercial activities.

On Christmas Eve 2010, Maroon inhabitants of Albina took to mass violence in response to the fatal stabbing of a Maroon by a Brazilian immigrant, after an argument over payment for a river transport. A crowd of 500 angry Maroons set upon the immigrants who were in the commercial area south of Albina. Supermarkets, hardware shops, hotels, restaurants, and petrol stations owned by Surinamese from Paramaribo and Chinese were plundered and torched, and their owners, employees, and customers beaten. Several Brazilians were injured and about twenty Brazilian women were raped. The looters took everything they could carry (Guimarães 2009a, 2009b, de Theije 2010). The money, over which the fatal fight evolved, was reportedly an overdue payment for smuggling between Suriname and French Guiana. This is a common and easy activity as there is little control on the river. The French Guianese have tried to introduce border controls in recent years to combat the transportation of supplies to illegal mining sites on the French territory, but they have to date not been very successful (Auriel 2012-2013). Moreover, on the Surinamese side of the frontier, there is barely any control so that people have been able to carry on the gold trade freely, and of course, the transportation of goods, fuel, and people. In the remainder of this section, the logic of trade in the trans-frontier space of the Lawa River is discussed.

The trans-frontier trade is a fundamental part of the economic activities in this region. Journalist Trommelen (2000) has told of his encounter with a Surinamese man who smuggled soft drinks from Suriname to French Guiana at the turn of the millenium. The man explained to him that the liquid in the small plastic bottles was produced in San Juan, Trinidad. From there it was imported to Suriname under the low Caricom tariff, brought to Albina, and then to Saint-Laurent-du-Maroni, finally ending up in Cayenne. Even with all the transport costs, by boat from San Juan to Paramaribo, 150 kilometers by car from Paramaribo to Albina, crossing the Marowijne by boat, 250 kilometers from Saint-Laurent-du-Maroni to Cayenne, the drink still arrived there cheaper than the locally produced soft drinks. And the smuggler still earned a good income. 
The opportunities that the trans-frontier space offers are also attractive for French entrepreneurs. Three weeks before the Christmas riots in Albina, I visited a friend in Maripasoula in French Guiana (see map). He helped me understand some of the forms of commerce on the river. I was doing fieldwork in Antino, in Suriname, and used the office of the radioman on the airstrip where I overheard a conversation between police officers about a citizen who was smuggling fuel from Albina to 'the French side.' Apparently this concerned a large quantity, not just a few barrels to keep the canoe motor going for a while. However, the discussion concentrated on the fact that the officers knew the transaction was happening, but their superiors had not given them the explicit order to apprehend the citizen. As I was told by the Maripasoula citizen, this was an established and highly respected French fuel trader, who was a provider of government diesel supplies. By buying the fuel cheap in Suriname and bringing it to French Guiana without paying import taxes, he was making a nice profit.

Thus, while bringing goods from Suriname to French Guiana is profitable because the prices are much lower there, there are other factors involved in this calculation. The prices of products and fuel are relatively stable at the moment of purchase in Paramaribo or Albina, but between the time of purchase and the sale, there are many variables that play a role. The prices are established according to the real costs of purchase, the costs of fuel needed for the transport, the difficulty of manoeuvring the boat to a certain location, the risks of being caught by the French police or military, and the saturation of the market. The most influential variables are a result of Operation Harpie, aimed at suppressing trans-frontier trade and small-scale mining in French Guiana. The confiscation and destruction of mining sites, equipment, and merchandise drives the prices up. Merchandise can easily be lost and the boats can be confiscated, and when the drivers and passengers are taken prisoner, they risk time in jail, or deportation. The entrepreneurs engaging in this business take the risks into account when calculating the profit margins. Thus, the 30-year old Brazilian, Branca, made some trips into French Guiana to sell clothes and drinks. She paid 30 grams of gold and two barrels of fuel to have 1000 kilos of merchandise transported up the Waki River. In eight days she sold everything for 350 grams. At 35 Euros a gram of gold, her investment was about 1400 Euros and her profit (12.250-1400) more than ten thousand Euros in a week. However, after three or four trips, she lost her merchandise and had to run from the police. She spent nine days walking in the bush, with a small group of others, before they reached the Lawa River and could cross to the 'safe' Surinamese side of the frontier. At this moment in her life she prefers not to return to the risks of trans-frontier hawking, and is staying in Suriname with her new 
husband and baby. However, she is not discounting the possibility of returning to that business one day.

The most important ingredient for small-scale mining operations is the fuel for running the pumps. The price for a barrel of fuel varies according to the distance and the season. In the dry season, when the rivers become difficult to cross, the price per barrel may double or triple. While a barrel of 200 litres in Paramaribo costs about 5 grams of gold, in an illegal mining site in French Guiana it may cost 50 grams, and in the dry season even more. The gold deposits are very rich and justify the immense investment. When it is too dangerous to bring the fuel by boat, the men carry it on their backs, in 40 litre jerry cans, walking many hours at night in the bush. These are called burros 'donkeys', in Portuguese, but they can earn up to seven grams of gold a trip. The danger and high rewards attract young men especially. Sitting on the porch in the evening, they recount their adventures. They all have been caught by the police at some time or another, but they enjoy telling their stories. One miner was arrested when he was carrying a small engine on his head, another had to take off his clothes, but they all agree that the French police are polite and treat them correctly. "If they beat me, I would stop doing this" one man said.

In the past few years several new settlements have sprung up on the Lawa River. One of these is Kabana-vo. A few years ago it was just a kampu 'camp' of an Aluku family, with three or four Surinamese and Brazilian families living there. From early 2008 this small settlement started to grow and a year later several hundreds of Brazilian and Surinamese people lived and worked in the place. During the day it is a slow-moving place, with some people hanging around in the bars and restaurants, at the hairdresser's or in one of the shops. At night or during the early morning, however, Kabana-vo bursts with activity as it is the departure point for smuggling people and goods into the Waki Creek and other garimpos on the French side of the river. Boats are filled with merchandise and mining gear, and leave before dawn to cross the part of the river that is controlled by the French police when it is still dark. Jaw Pasi is a similar place, further up the Lawa River, in the customary territory of the Wayana Amerindians. Until 2009, Jaw Pasi was just a landing with three houses and a small grocery shop. It started growing after the French Operation Harpie began when it became more difficult for people to stay in French Guiana without residence and working permits. In the first year about thirty new houses were built, and about a hundred more or less permanent inhabitants settled. Most of them are engaged in some sort of trade, on either side of the river, many of them transporting drums of oil on their backs in the dark of the night. In the last eighteen months, several Chinese entrepreneurs have set up supermarkets there, and they have now forced the Brazilian shop owners out of the market, just as 
happened a few years ago in Benzdorp and other places. They also compete with each other, and the prices are now considerably lower than they were before. As a result, the inhabitants who live from selling to illegal miners in French Guiana no longer purchase the merchandise and fuel in Paramaribo or Albina but rather directly at the local Chinese shops.

The arrival of the supermarkets also affects the local population. The Wayana Amerindians at Antecume Pata are happy with the new cheaper Chinese supermarkets on the Surinamese border of their river, and they see it as an improvement in the quality of their life to have better access to many products from the city. The most visible result of the increased commercial trade activities at the Lawa are the eighteen Chinese supermarkets in a row on the riverside right opposite Maripasoula. This settlement, called Antonio do brinco (Anthony with the earring, after the first Brazilian man to build a commercial house at this location), has grown rapidly in the past three years. The shops not only cater for the miners, but also for the residents of the French villages in this region. Thus French and Chinese can now be added to Sranantongo, Ndyuka, Aluku and Portuguese that already have a long history as commercial languages along the Lawa border. Also, at this new "shopping mall" the goods are no longer brought to the camps of the costumers; rather the supermarkets have their own canoes that take their customers from the French border to the Surinamese riverside, free of charge.

Conclusion

The movements in and out of Suriname are also movements in and out of French Guiana. In this chapter, the focus was on the movements for economic practices, but there are many other reasons to physically move between the two countries. The children who live on the Surinamese side of the Lawa go to school in French Guiana, because there are no schools in this part of Suriname. Everyone, adults and children, Amerindians, Maroons and Brazilians alike, also seeks medical help in Maripasoula because there are no doctors or hospitals on the Surinamese bank of the river. The Brazilian and Surinamese illegal gold miners believe there is more gold to be won in French Guiana than in Suriname, and in their wake go the traders and hawkers who bring fuel and merchandise from Suriname to French Guiana because it is much cheaper to buy it in Suriname. For the same reasons, the inhabitants of French Guiana living in this region prefer to do their shopping in Suriname.

The trans-frontier economic space described in this article is not a new phenomenon. More than a hundred years ago there was already trade across 
the border and one author mentions gold prospectors who were expelled from Suriname because they had no legal documents and returned to French Guiana that way (Petot 1986: 123). The border has never been a complete barrier and the people who have to deal with it show a lot of flexibility in their economic practices. The frontier is intended as a means to control and thereby limit people's movements, but in practice it creates many opportunities. As mobile social agents, the merchants, traders, miners, and hawkers described in this chapter develop different practices in response to the circumstances created, on the one hand, by nation-states, and on the other hand, by the practices of other agents within the trans-frontier social space, finally of course, by addressing their own specific needs. 